\title{
Ideological Dilemmas Actualised by the Idea of Living Environmentally Childfree
}

\author{
Erik Nakkerud ${ }^{1,2}$ (D)
}

Received: 24 June 2021 / Revised: 24 September 2021 / Accepted: 27 September 2021

(C) The Author(s) 2021

\begin{abstract}
Over the past decade, the choice of living childfree has increasingly been viewed as a proenvironmental behaviour. Recent research has investigated statistical relations between environmental concern and reproductive attitudes, as well as exploring the processes around actually deciding to live environmentally childfree. Based on increased public attention about the phenomenon, this article employs Michael Billig's notion of ideological dilemmas to analyse the media coverage of choosing to live environmentally childfree, attempting to answer how these dilemmas influence whether living childfree is perceived as a relevant pro-environmental behaviour. Thirty-one news items were analysed using a synthesis of critical discursive psychology and thematic analysis. The analysis identified five ideological concepts: liberalism, sustainable development, globalism, biologism and humanism. Each of these concepts contains positions supporting and opposing the idea of living environmentally childfree in Norway. These ideological dilemmas seem to weaken the perceived relevance of living environmentally childfree, as the topic is easily dismissed or framed as irrelevant. I therefore conclude that the discourse of living environmentally childfree is analogous to how society generally relates to solutions to the environmental crises.
\end{abstract}

Keywords Pro-environmental behaviours · Population · Childfree · Ecological impact · Ideological dilemmas

\section{Introduction}

The topic of human overpopulation has long historical roots, going back at least to Malthus (1798) who argued that the power of population growth is indefinitely greater than the Earth's ability to produce food. Older estimates found the optimum human population size to be within the range of 1.5 to 2 billion people (Daily et al., 1994), while more recent estimates conclude that with an array of measures implemented, it

Erik Nakkerud

erik.nakkerud@psykologi.uio.no

1 Department of Psychology, University of Oslo, Post Box 1094, Blindern, 0317 Oslo, Norway

2 Department of Psychology, Bjørknes University College, Lovisenberggata 13, 0456 Oslo, Norway 
is achievable to feed 10 billion people within planetary boundaries (Springmann et al., 2018). The latter number is within the latest estimates of what size the global human population will stabilise (Vollset et al., 2020).

Running in parallel with these demographic estimates and debates at the macro level is a trend where people personally decide not to have children because of environmental concern (e.g. Fleming, 2018), often referring to calculations of the ecological impact of having children (Murtaugh \& Schlax, 2009; Wynes \& Nicholas, 2017). Others see the personal restriction of reproduction as a way of striking, where they refuse to have children until politicians take considerable environmental action (Hunt, 2019).

Existing research has looked at the statistical relations between environmental concerns, pro-environmental behaviours and reproductive attitudes, generally finding that environmental concern does indeed predict less positive attitudes towards having children (Andrijevic \& Striessnig, 2017; Arnocky et al., 2012; Davis et al., 2019). A qualitative study explored some of the psychological and social processes surrounding the choice of restricting reproduction to zero children or one child out of environmental concern (Nakkerud, 2021), using the term living environmentally childfree. As a potential pro-environmental behaviour, living environmentally childfree is even categorised as a high-impact behaviour in terms of its ecological impact (Wynes \& Nicholas, 2017).

An analysis of the public conversations on fertility in Norway showed how these conversations relate to both a national welfare state crisis and a global climate crisis (Kristensen, 2020). Still, it does not seem conventional to connect the question of reproduction to the environmental crises. For instance, in a study where Norwegians were asked to freely formulate solutions for tackling climate change, only 53 of the 4634 responses mentioned solutions related to reproduction and population (Tvinnereim et al., 2017). Thus, there seems to be a potential paradox: While choosing to live environmentally childfree is an obvious pro-environmental behaviour in terms of its ecological impact, it is to a far lesser extent actually viewed as a relevant pro-environmental behaviour, at least in Norway. Nakkerud (2021) suggested that parts of the answer to this apparent paradox might have to do with ideology. In this study, people who had chosen to live environmentally childfree were interviewed, and when discussing the reactions they received from others, these were often related to common-sense assumptions regarding topics like the welfare state and the biological clock.

Similar common-sense assumptions are evident in Kristensen's (2020) analysis as well, where the sustainability of the national welfare state and sustainability of the global environment are in conflict. This conflict illustrates how a concept like sustainability might involve opposing views, where both are based on a commonsensical approach to the same phenomenon. This illustrates the concept of ideological dilemmas, where conflicting views on the same phenomenon are based on commonsensical understandings derived from the same ideology (Billig et al., 1988). More specifically, the theory of ideological dilemmas suggests that each society has an overarching contemporary ideology, and that this ideology is visible in everyday thinking and everyday concepts. Further, these concepts have opposing positions within them, which means that the contemporary ideology's concepts might be used both to support and oppose any given topic. An example is the concept of equality in the discourse around poverty, where sympathy and blame represent conflicting views that both are based on an understanding of equality: "on the one hand it is good to show mercy, but on the other hand too much mercy will undermine justice" (Billig et al., 1988, p. 41). The conflicting views based on the concept of sustainability in the discourse around fertility rates (Kristensen, 2020) may be formulated in similar terms: on the one hand, we need 
children as future taxpayers and to take care of the elderly, but on the other hand, too many children will undermine ecological sustainability.

Whereas Kristensen (2020) approached the conversations on fertility in general, the aim of this article is to analyse public conversations on living environmentally childfree, attempting to explore further the role of ideologies in understanding the paradox described above. More specifically, the aim is to answer the following research questions: What ideological dilemmas are represented in the contemporary Norwegian media coverage of choosing to live environmentally childfree? How do these dilemmas influence whether living childfree is perceived as a relevant pro-environmental behaviour?

\section{Methodology}

\section{Materials}

As there is no established terminology for speaking about the choice of living childfree out of environmental concerns, it was deemed unfeasible to settle search terms that would yield meaningful results in search engines for news items. Furthermore, some of the relevant items do not mention childfree explicitly, while nonetheless addressing topics or expressing discourses that are valuable for the analysis (e.g. Aftenposten, 2020). Instead, the selection of news items followed a manual, two-step procedure: first, by trying to keep track of the Norwegian media coverage in newspapers, on radio and on TV, between September 2017, when the project was started, and October 2020, when selection of items ended as the analysis begun; and second, by finding news items referred to in the first step, analogous to snowball sampling with human participants (Browne, 2005). Some items from before 2017 were thus selected. However, to maintain the contemporary context, the majority of items are from after 2017, with the oldest being from 2013.

All the news items included for analysis are from Norwegian newspapers and broadcasters. There were two main reasons for this choice. First, it seemed more realistic to have an adequate overview of the national media coverage in the author's country of residence. Second, restricting items to the Norwegian context would allow for triangulation when comparing the analysis with the results from a recent study that explored the choice of living environmentally childfree in Norway (Nakkerud, 2021). The 31 news items are listed in Table 1, including brief descriptions of their content.

\section{The Norwegian Context}

As the present study is restricted to Norway, a few relevant remarks about the Norwegian context must be made. Despite issues related to the health system's geographical and social equity (Ringard et al., 2013), the Norwegian welfare state is generally characterised by universal and equal access to services (Greve et al., 2021). These services include family policies, which scholars argue have kept the declining fertility rates at relatively high levels when the same rates have been declining more rapidly in other Western countries (Comolli et al., 2020). An analysis of Norwegian family policies concluded that there is a political consensus about children being a public good and a public responsibility, and that pronatalistic policies are legitimatised through reference to the people's welfare (Ellingsæter, 2012). 


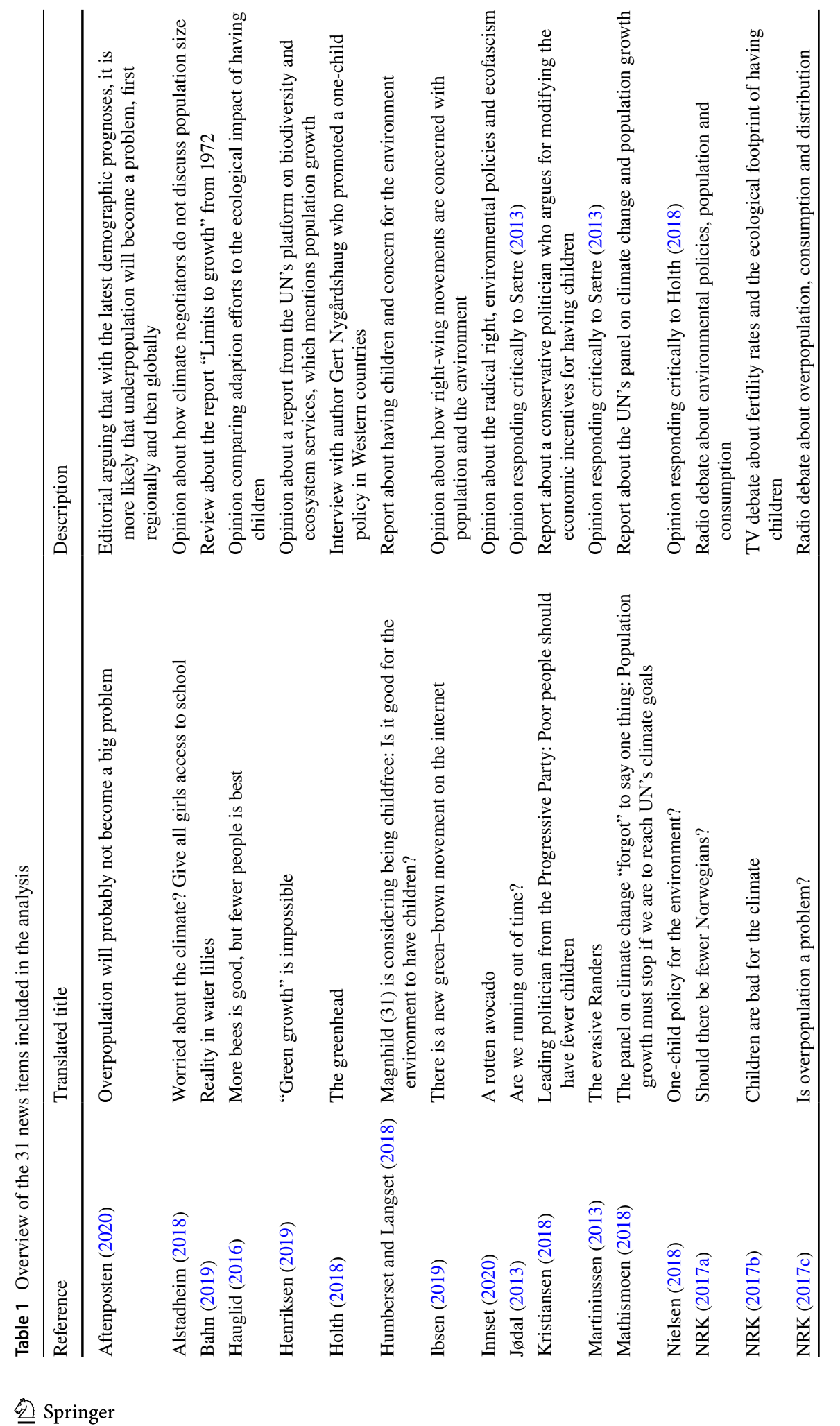




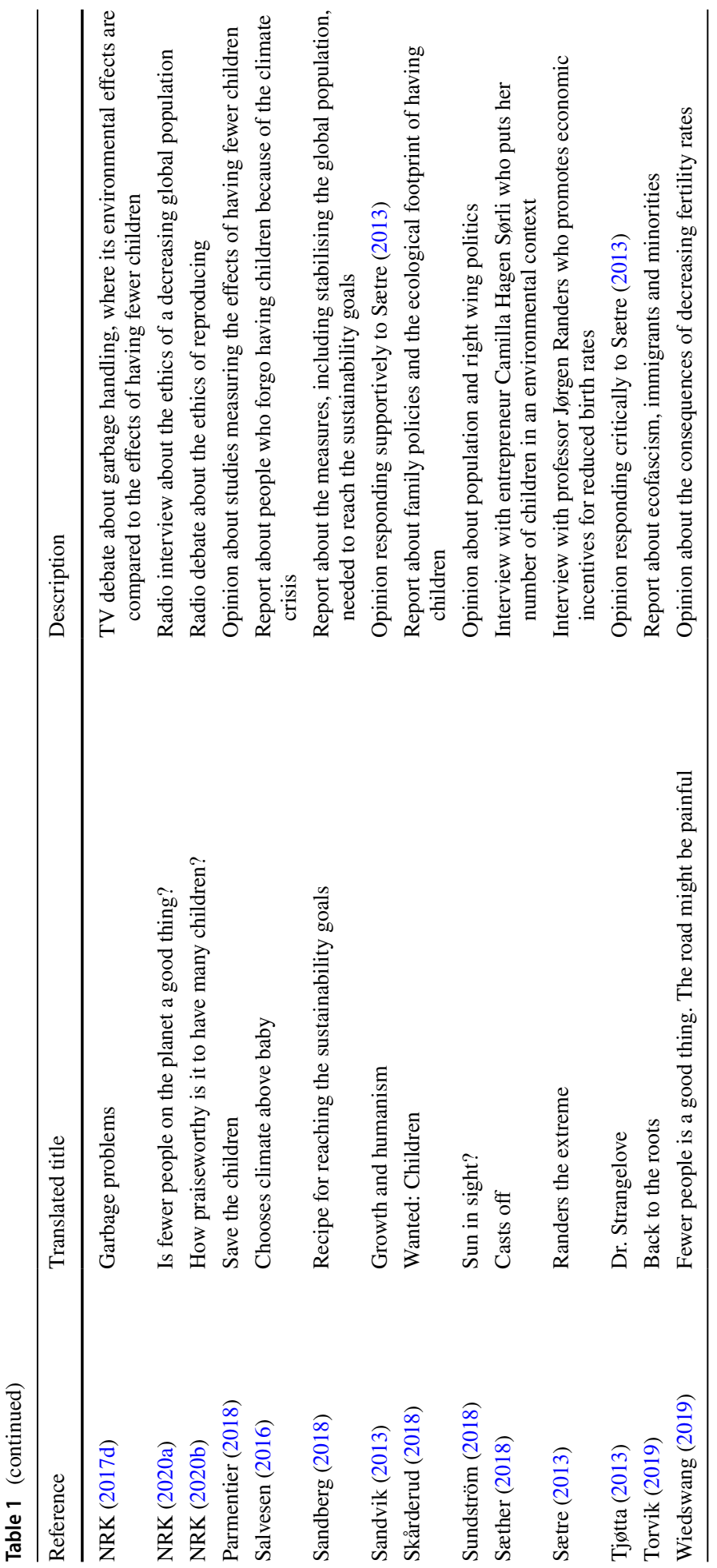


The Norwegian welfare system, including generous family policies, is usually associated with the country's petroleum resources, manifested in the Norwegian Government Pension Fund, the world's largest sovereign wealth fund (Lie, 2018). While both Ellingsæter (2012) and Kristensen (2020) showed how concern for the welfare state's sustainability plays a part in the public discourse surrounding fertility rates, a recent report surprisingly suggested that decreasing fertility rates are actually good for the Norwegian state finances (Bjertnæs et al., 2019). This partly has to do with the Pension Fund's unique position in the Norwegian economy, which allows for the fact that the average Norwegian receives more from the state than she or he pays in taxes. This discrepancy is covered by spending parts of the revenue from the Pension Fund. Thus, with decreasing birth rates, fewer people will have to share the revenue, thereby delaying the moment where the fund's revenue will not be enough to cover the deficits in the national budget.

While the Norwegian state finances currently enable generous family policies that support reproduction, Norwegian scholars have a tradition for looking at phenomena related to reproductive decisions. These include parenthood by choice (Ulvik, 1993) and living childfree (e.g. Fjell, 2008). Ulvik (1993) interviewed 31 women to investigate how new modes of contraception, access to abortion and other social changes influenced couples' decision-making processes. Fjell (2008) used the term childfree in her cultural analysis of the phenomenon, while Sveen (2015) edited a book with multiple perspectives on the same topic, including environmental concern, using both childfree and voluntarily childlessness as terms. Andersen (2020) interviewed eight women and men for her sociological analysis of the wish to live childfree. Finally, in a recent survey about fertility, working life and family policies, the respondents were asked to what degree environmental concerns played a part in not wanting more children, finding that such concerns were relatively more important for men than for women (Cools \& Strøm, 2020).

The presence of and scholarly interest in living childfree, with or without environmental concern, might be related to how Norway has traditionally been viewed as one of the so-called individualistic countries, as opposed to collectivistic countries (Hofstede, 2001), a view that has been supported by different methodological approaches (Kolstad \& Horpestad, 2009; Nafstad \& Blakar, 2009). In individualistic countries, it is perhaps to be expected that questions with macro-level implications are explored as individual decisions. This individualism is illustrated, or even caricatured, in a quote from the Norwegian government's newly released climate action plan for 2021-2030: "The climate policy will never be better than the sum of free choices from millions of humans" (Norwegian Ministry of Climate \& Environment, 2021, p. 14).

\section{Theoretical Framework and Analytical Approach}

Billig and colleagues (1988) used the term ideological dilemmas to illustrate and discuss how common sense and contemporary ideology are characterised by contrary themes. Contemporary ideology contains opposing themes through what they called dilemmatic aspects, which enable debate between positions within the same ideology. Such ideological dilemmas are the framework of the present study. Furthermore, Billig and colleagues (1988, p. 26) directed particular attention towards individualism, observing how "the great ideas of individualism have been transformed into everyday concepts, which possess dilemmatic qualities". As noted above, individualism is still relevant for the Norwegian context. Thus, the analysis included concepts derived from the same "great ideas of individualism". However, whereas Billig and colleagues' (1988) approach builds on one contemporary 
ideology with several everyday concepts, the present analysis ended up looking at concepts which can themselves be viewed as ideologies, such as liberalism and humanism. Thus, the analysis operates at the level between grand contemporary ideology and its concepts in everyday thinking. For the sake of clarity, these are referred to as ideological concepts.

Regarding the analytical approach, the ideological dilemmas were identified and categorised following Braun and Clarke's (2006) steps for thematic analysis. The ideological concepts were viewed as main themes, identified in an inductive way. Further, the analysis was interpretive in how it looked for latent themes. The analysis progressed as a cycle between two modes: (A) identifying parts of the material that involved positioning on the topic of living environmentally childfree and (B) categorising the parts into ideological concepts. As concepts were categorised, the identification of positioning could look for more specific ideological dilemmas, which again influenced the categorisation of concepts, thus creating an analytical cycle. In this cycle, the analysis was inspired by how critical discursive psychology uses ideological dilemmas as well as interpretative repertoires and subject positions to analyse how discourses are shaped (Wiggins, 2017). Through the analysis, it became evident that the dilemmas, repertoires and positions represent contrary themes not just within the concepts, but also across concepts, where a position in one concept is related to another position in another concept, as opposition or agreement.

While ideological dilemmas (Billig et al., 1988) are a common analytical tool in critical discursive psychology (Wiggins, 2017), it is perhaps less common to use thematic analysis (Braun \& Clarke, 2006) in the way described here. However, such a synthetic approach is supported by Watts (2014), who argue for an analytical approach based on the user rather than the tools, allowing the researcher to apply the different methods in the ways she or he needs to create engagement with the data.

\section{Analysis and Discussion}

The ideological concepts were identified through the analytical cycle described above. First, any position on the topics of living environmentally childfree, reproduction, environment and population were identified. Related positions were then grouped together, before the groups were ultimately categorised as five ideological concepts with dilemmatic aspects: liberalism, sustainable development, globalism, biologism and humanism. While a concept like liberalism usually refers to a political ideology, the concept here refers to everyday thinking regarding the individual's rights and responsibilities. Sustainable development, on the other hand, is perhaps viewed as more descriptive than ideological. Here, the term is used as an ideological concept because its use in everyday thinking reveals opposing themes on the present topic. What the identified ideological concepts have in common is that they operate at the level between grand ideology and everyday concepts.

While the themes were identified through an inductive thematic analysis, it is worth nothing that the themes also relate to existing debates on the topic of reproduction and environmental issues. Liberalism relates to research on the human rights aspect of planning families (Hamity et al., 2019) and to research that addresses the topic's conflict between individual freedom and individual responsibility (Rieder, 2016). Sustainable development relates to the already-mentioned analysis on the conflict between ecological sustainability and socioeconomic sustainability (Kristensen, 2020). Globalism relates to initiatives that connect development programmes to the issue of overpopulation (Mayhew et al., 2020). Biologism relates to the concept of demopopulationism, which includes "continued 
attempts to suppress the fertility of some and enhance the fertility of others" (Bhatia et al., 2020 , p. 337). Finally, humanism relates to the contrast between hope and fear regarding children's environmental future (Helm et al., 2021).

The categorisation into five ideological concepts does not cover all the positions initially identified. For instance, a few positions with a religious approach to the topic were identified, but not included in the final analysis as they lacked the dilemmatic aspects. Similarly, feminist positions were also identified, but these were grouped into other ideological concepts, like liberalism (e.g. women's rights) and sustainable development (e.g. reducing fertility rates through providing education, jobs and health services for women).

The results from the analysis are presented in two parts. The first part presents the ideological dilemmas within each of the concepts, while the second part presents how the positions might also interact across the concepts. As Table 2 illustrates, the dilemmas might be represented as arguments supporting or opposing the idea of living environmentally childfree in Norway. This is in line with the notion of opposing positions within a contemporary ideology (Billig et al., 1988), and the analysis will be based on the contrasts between these positions. Table 2 also includes illustrating excerpts from the media items, with further excerpts related to the ideological concepts presented in the text. The original versions of all translated quotes can be found in the Appendix.

\section{Liberalism}

In this context, liberalism refers to a position that emphasises the importance of individual freedom, meaning that also actions performed for a collective good should be the result of an autonomous decision. While this concept could also be labelled individualism, liberalism is preferred because it is then distinguished from the grand ideology of individualism (Billig et al., 1988). In other words, liberalism is here understood as one of many expressions of individualism. In any case, the freedom to pursue meaningful experiences and well-being is fundamental to this position. Thus, the ideological concept of liberalism opposes the idea of not having children out of environmental concern, since it puts a collective good above the personal, potentially transformative, experience of having children. More importantly, having children is a right that no one should interfere with (Excerpt B, Table 2). However, this right is also a right not to have children, accentuating the freedom of living without children, regardless of the ecological impact. Thus, as an ideological concept, liberalism might support the choice of living childfree for personal reasons, while at the same time opposing the choice of living childfree out of environmental concern.

In contrast, the emphasis of autonomy implies that liberalism might also support the idea of living environmentally childfree. Autonomy means responsibility, and the individual is responsible for making informed environmental actions (Excerpt A, Table 2), where not having children is one with a very high impact (Wynes \& Nicholas, 2017).

A further complication of this ideological dilemma is that the position in which liberalism supports the choice of living environmentally childfree might be accused of approaching a systemic crisis in an individualistic way. This implies a third position, not using liberalism to either support or oppose the choice of living environmentally childfree but refusing liberalism as a relevant ideological concept for solving the environmental crises. This excerpt illustrates such a third position:

Even if we accept the idea that having children should be assessed in the same way as flying to Bali, we are still left with a far more fundamental question: Can you, as an individual, do anything at all to mitigate climate change? Does it matter, in the big 


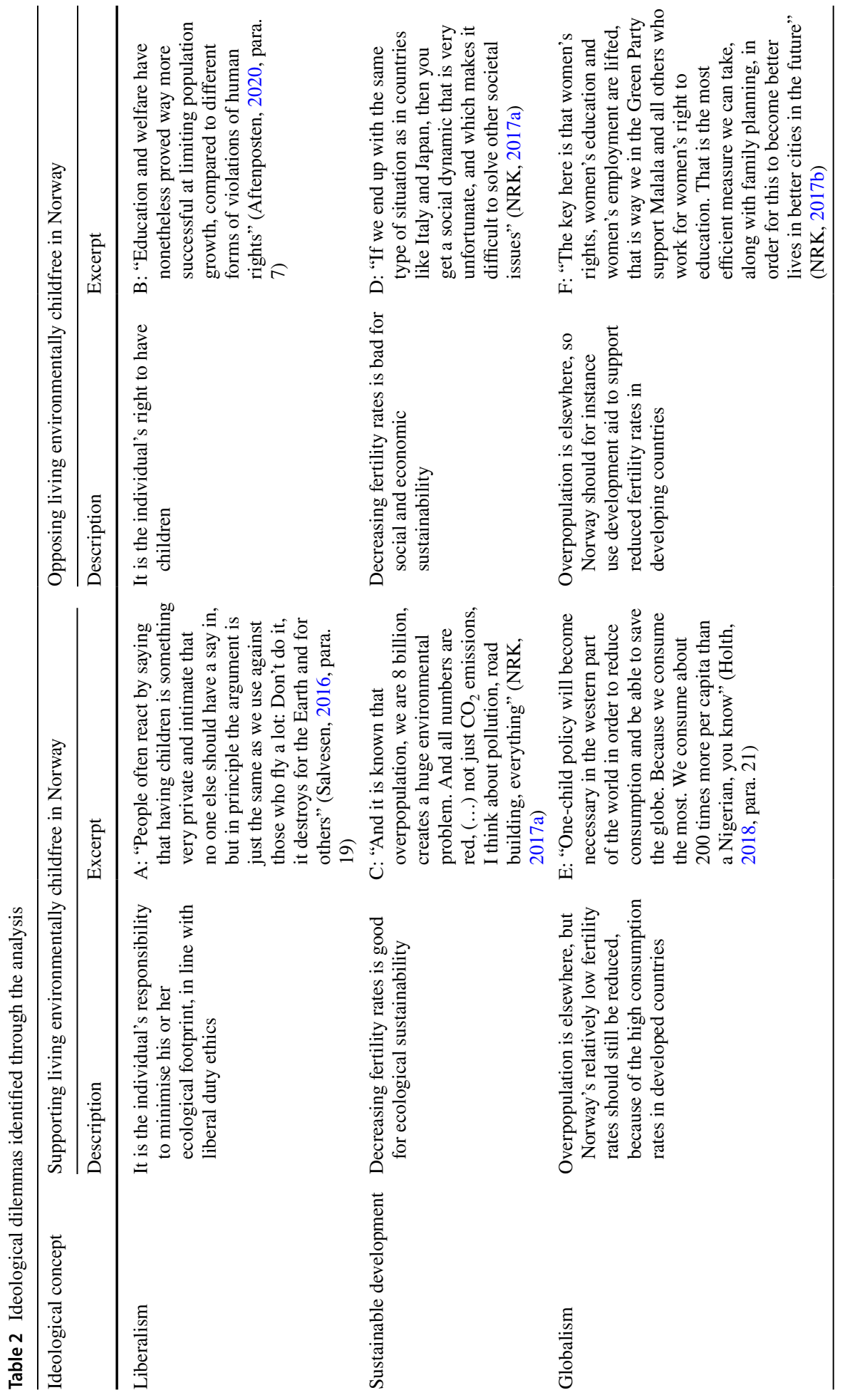




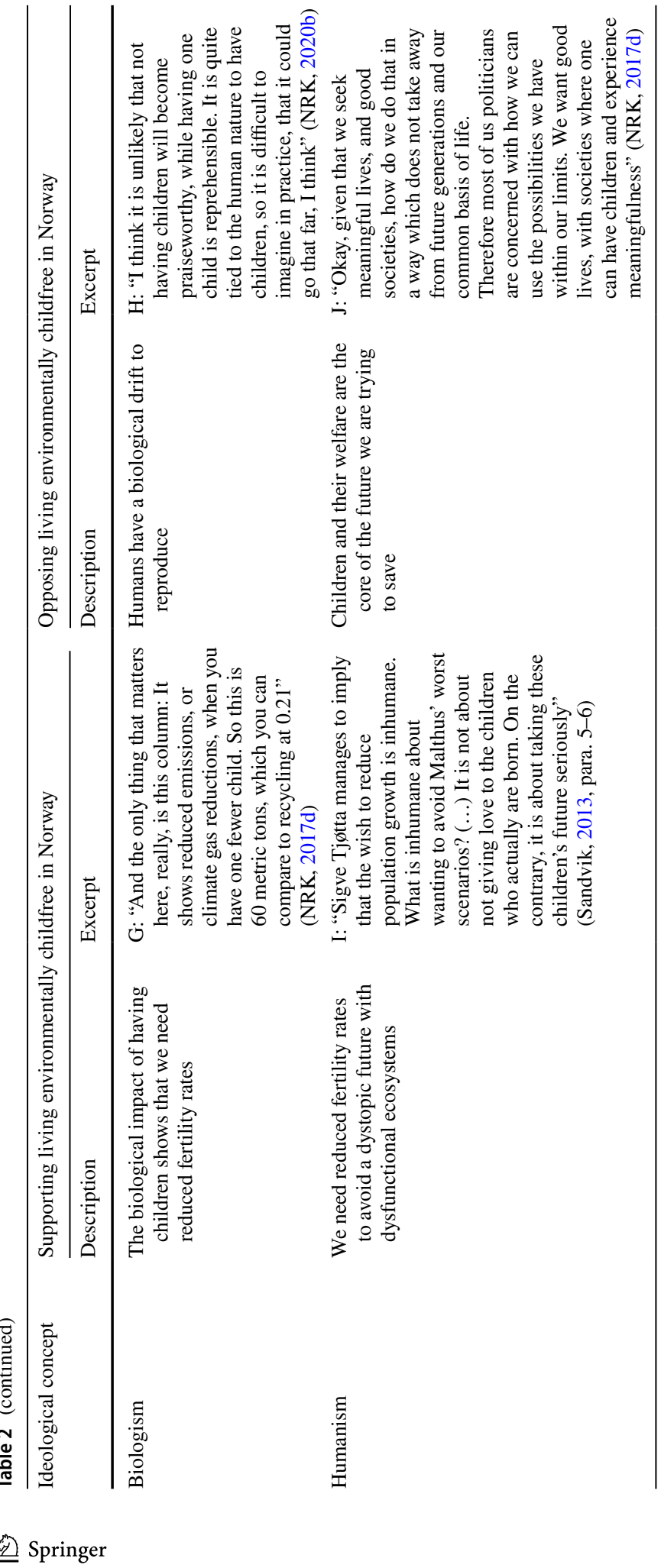


picture, whether you choose to live a childfree or car-free life? (Parmentier, 2018, para. 4).

What the third position shows is that the question of living environmentally childfree might quickly end up in a theoretical discussion about the responsibility of individuals and systems. While this discussion is important when it comes to mitigating the environmental crises, the consequence is nonetheless that a choice with arguably high impact is viewed as a distraction from more fundamental questions, such as whether it really matters what an individual does.

\section{Sustainable Development}

The ideological concept of sustainable development refers to how policies and human action must take into account the sustainability of these policies and actions. However, sustainable development has at least three components: ecological, economic and social sustainability. These are of course interrelated, but it is still common to distinguish between the three (Harris, 2001). Emphasising the ecological component, the ideological concept of sustainable development supports living environmentally childfree, arguing that fewer children means less strain on the environment (Excerpt $\mathrm{C}$, Table 2). In contrast, when emphasising the economic and social components, it opposes living environmentally childfree, arguing that fewer children means more strain on the future of the welfare state (Excerpt D, Table 2). This is in line with Kristensen (2020), who suggested that the Norwegian public discourses on fertility rates move between climate crisis and welfare state crisis.

A debate in the Norwegian newspaper Morgenbladet illustrates the tension between the opposing themes within the ideological concept of sustainable development. It started with a professor in economics arguing for a one-child policy (Sætre, 2013), using the ecological component of sustainable development. Two replies (Jødal, 2013; Tjøtta, 2013) to this feature illustrate how concepts like innovation and economic growth are used to support the economic and social components of sustainable development, thus opposing the idea of living environmentally childfree, as in this excerpt:

I believe it is in our nature to think that resources and the ecology is limited. Everything we like, want and need is limited in the short term. However, there is another side of our nature that might be easily overlooked: Humans are productive, innovative and creative, and are able to create a better world in the long term (Tjøtta, 2013, para. 3).

As the debate moved on, the ecological component of the concept was yet again emphasised, supporting the idea of living environmentally childfree: "The problem is that business as usual lack any physical, mathematic, ecological, geographic, demographic and climatic realism" (Sandvik, 2013, para. 1).

The ideological dilemmas related to sustainable development seem to have a big influence on the perceived relevance of living environmentally childfree. More specifically, the sustainable development theme that opposes the idea of living environmentally childfree does this in a way where the idea is perceived as understandable, but irrelevant. This position acknowledges the environmental concern behind connecting reproductive choices to the environmental crises, before arguing that distribution of resources and innovation of technology will have a bigger impact than choosing not to have children, meaning that the latter is less relevant. Furthermore, it suggests that a position that only looks at the ecological impact of individual behaviours could run the risk of overlooking collective action and 
social change. However, this objection might be a straw man, as the movements BirthStrikers (Hunt, 2019) and \#NoFutureNoChildren (Gaviola, 2019) illustrate how the phenomenon is not necessarily just a private-sphere pro-environmental behaviour.

\section{Globalism}

In this context, globalism refers to the idea that issues like climate change and environmental crises need to be viewed through a global lens, not focusing on only local, national or regional aspects. The ideological concept of globalism supports living environmentally childfree in Norway by arguing that even though Norway has low fertility rates, the country's consumption is much higher than in other parts of the world (Excerpt E, Table 2). In opposition to this, the concept can also be used to argue that rather than having less children in Norway, the focus should be on reducing the fertility rates in the parts of the world where these are much higher (Excerpt F, Table 2).

Interestingly, the opposing themes within this concept can be combined by the same actor, creating a position that in terms of globalism seems unimpeachable. In such a case, globalism is used to advocate reduced fertility rates in both Norway and developing countries, as in this excerpt:

One of the most important measures I can imagine, then, besides educating young people in developing countries, and besides helping women with better health and reproductive health, is to reduce the number of children in the rich part of the world (NRK, 2017c).

However, when the opposing themes within globalism are represented by different actors in a debate, the result might rather be confusion. When the arguments switch between what should be done in Norway and what should done in developing countries (e.g. NRK, 2017b), it results in a kind of "whataboutery" (O'Connell, 2021), which means that an argument about topic A is countered by reference to topic B (i.e. "What about B?"). Here, whataboutery is practiced by introducing measures in developing countries instead of directly addressing the idea of having fewer children in Norway. The consequence, then, is that the topic of living environmentally childfree is implicitly refused or framed as irrelevant.

\section{Biologism}

As an ideological concept, biologism here refers to how human actions are understood from a strictly biological point of view. Biologism supports the idea of living environmentally childfree by emphasising the strict ecological impact of having children, and disregarding other perspectives like meaning-making and well-being (Excerpt G, Table 2). At the same time, biologism may also oppose the idea of living environmentally childfree by referring to how it is part of human nature to produce offspring (Excerpt $\mathrm{H}$, Table 2).

Biologism might also include an emphasis on race. To see the potential racism in biologism in the current context, it is necessary to look at a combination of perspectives and statistics that by themselves are not explicitly racist. Two such perspectives regard the need for Norwegians to produce more children (Skårderud, 2018) and the suggestion that the government should restrict the number of children poor families are allowed to have, making reference to the programme for child benefit (Kristiansen, 2018). As immigrants from non-European countries both are less economically integrated (Brovold, 2020) and have 
higher fertility rates (Andersen, 2021) compared to the population average, the statements about child production and child benefit suggest a distinction between the children we need more of and the children we need less of. This reveals how the ideological concept of biologism potentially has racist connotations. Furthermore, several of the analysed news items warned about the connection between environment and population, on the one hand, and racism or fascism on the other (Ibsen, 2019; Innset, 2020; Sundström, 2018; Torvik, 2019). Scholars have also investigated this connection, which Bhatia (2004) refers to as white nativist environmental movements. Similarly, Aufrecht (2012) referred to "the greening of hate" in her analysis of how immigrants are blamed for environmental issues in the USA.

The racist connotations have implications for how the topic of living environmentally childfree is treated, for both those who are concerned with the implicit racism and those who are not. For those who are concerned, it does not matter whether they embrace the impact-focused perspective behind living environmentally childfree, as the racist connotations discredits this perspective (e.g. Sundström, 2018). While for those who are not concerned about these connotations, the question is seemingly more about demographic impact than ecological impact (Bhatia et al., 2020). In both cases, the consequence is that the choice of living environmentally childfree is not discussed as a way to mitigate the ongoing environmental crises.

\section{Humanism}

As with the other ideological concepts in the present analysis, humanism may both support and oppose the idea of living environmentally childfree in Norway. Supporting the idea, a humanistic perspective emphasises that less people is the most effective measure if we want to avoid a dystopic collapse of ecosystems and societies. Thus, having fewer children is the best way to provide a good future for those children who are actually born (Excerpt I, Table 2). In opposition to this, a humanistic perspective supports having children despite the environmental crises, because future children are the very reason for solving these crises, meaning they must be solved in other ways (Excerpt J, Table 2).

The notion of "the greening of hate" in the subsection above is characteristic of a humanism-based opposition to the idea of living environmentally childfree. While not denying the ecological impact of a lived life, this use of humanism would rather emphasise how introducing reproduction as relevant for pro-environmental behaviours might open up for population control or similarly inhumane practices (Torvik, 2019). Again, it seems like the position opposing the idea of living environmentally childfree dominates the supporting position, as objections related to whom we are saving the future for if not for our future children, and the fear of inhumane practices, result in a rejection of living environmentally childfree as a relevant pro-environmental behaviour.

\section{Ideological Interaction Across the Concepts}

The analysis above shows how all five ideological concepts identified through the analysis contain opposing themes regarding the idea of living environmentally childfree. Because of this, any position on the topic might be countered not just by an opposing position within the ideological concepts, but also by opposing positions from the other concepts. Similarly, a position might be strengthened by drawing on support from the same position within another ideological concept. 
One example of how the ideological dilemmas might interact across the concepts is the use of biologism and globalism in opposing the idea of living environmentally childfree. While referring to how reproduction is a part of human nature can be considered as a rather innocent form of biologism (Excerpt $\mathrm{H}$, Table 2), the analysis above reveals how this position might be understood as having racist connotations by implying that we need more white children and less non-white children. However, the same position can also be supported by globalism, where Norway's low fertility rates are compared to the high fertility rates in many, especially African, developing countries (Nielsen, 2018; Wiedswang, 2019). The solutions offered by this type of globalism, such as education and health programmes (Excerpt F, Table 2), are certainly not explicitly racist, but the implication is nonetheless the same as with biologism: support for a reduction in the number of non-white children born in developing countries.

In opposing the idea of living environmentally childfree in Norway, globalism might also interact with the ideological concept of sustainable development. This is the case when people argue that the fertility rates in Norway are not sustainable in terms of the social and economic development, directly or indirectly concluding that a reduction in the average global fertility rates instead must come from the countries with higher fertility rates (NRK, 2017b).

Another example of interaction between the ideological concepts is cases where a position acknowledges the opposing position in a different ideological concept, presumably to increase the credibility of one's own position. This was the case in a debate where one participant first acknowledged that human actions should be assessed in terms of their ecological impact (i.e. biologism supporting the idea of living environmentally childfree). He then went on saying that it is more important to focus on education and health care in developing countries (i.e. globalism opposing the idea of living environmentally childfree) and address the problematic social dynamic of low fertility rates (i.e. sustainable development opposing the idea of living environmentally childfree) (NRK, 2017a).

The different positions' use of numbers is yet another example of interaction between the ideological concepts, where numbers regarding the ecological impact of having children may be countered with numbers showing, for instance, that fertility rates are indeed going down. The excerpts below are from the same radio debate, where persons $\mathrm{A}, \mathrm{B}, \mathrm{C}$, and D discuss reproduction and climate impact, and they illustrate how numbers from different domains are used:

A: The effect of having one child less is 25 times bigger than the effect of living car-free, when looking at the climate impact. (...)

B: In Norway, this is not a problem. We have a fertility rate at 1.7 children per woman. (...)

C: We know that in some African countries, almost $70 \%$ of all girls are married before they turn 18 years, and will likely have two children before turning 18 . (...) D: Several of us have said that Norway now has 1.7 children per woman, and looking into the future, that is not sustainable either, especially regarding the welfare programmes we have today. (...)

C: I heard Kenya was mentioned earlier, the last 60 years they have increased from a population of 7 million to a population of 49 million. Of course that creates problems. (...)

B: Where [C] makes it too easy for himself, is by saying that just quantity matters. We for instance have 3000 billion trees in the world, but there is no overpopula- 
tion of trees. We have 10,000 million, billion ants in the world, but there is no overpopulation of ants.

A: They do consume less than we do (NRK, 2017b).

A researcher interviewed in a feature on the topic suggests a possible solution to this game of numbers: "If overpopulation is a problem? You can say that all our environmental problems would have been smaller if we were fewer people" (Salvesen, 2016, para. 67).

As with the ideological dilemmas within the concepts, these examples illustrate how the childfree life ends up being framed as an irrelevant pro-environmental behaviour. A final example that demonstrates this is an interaction between sustainable development and globalism. This interaction emphasises Norway's relatively low fertility rates, pointing at how the sustainability of the welfare state actually demands that we increase our fertility rates. Further, the interaction may use globalism to emphasise that Norway could support decreasing fertility rates in other countries instead. Thus, it acknowledges the environmental concern behind choosing to live environmentally childfree, while nonetheless suggesting that this choice is irrelevant in Norway. In a study exploring the choice of living environmentally childfree, several participants reported that they were met with reactions similar to what is discussed here: While their reasoning was viewed as correct, they were told that this was an issue in countries with high fertility rates, not in Norway (Nakkerud, 2021).

\section{General Discussion}

The analysis suggests that for each of the ideological dilemmas, as well as the interactions between them, there are different ways through which they influence our perception of whether living childfree is relevant as a pro-environmental behaviour. For instance, the dilemmas illustrate how conversations on the topic have the potential of quickly collapsing into whataboutery, as any position on the topic might be countered by opposing positions within the same ideological concept or from other ideological concepts. This will often imply that rather than having its relevance as a pro-environmental behaviour thoroughly assessed, the idea of living environmentally is simply dissolving into discussions about other topics.

In her analysis of reproductive discourses in Norway, Kristensen (2020) showed how immigration might serve as such a topic, in two different ways. In one way, the question of fertility rates in general may evolve to the more specific question of fertility rates among immigrant groups. In another way, the suggestion of mitigating decreasing fertility rates through increased immigration is countered by a preference for biological reproduction. These shifts from fertility rates and reproductive concerns to issues of immigration illustrate the concept of demopopulationism (Bhatia et al., 2020). The authors behind this concept warned that attempts at discussing reproductive choices in the context of climate change and environmental impact might conceal suppressive ideas regarding which groups of people should have children and which groups should not.

Dilemmatic aspects of the ideological concepts discussed here are evident outside of the Norwegian context as well. A content analysis of reader comments on articles discussing going childfree in response to climate change, in English-language newspapers, identified arguments for why reproduce and why not reproduce (Helm et al., 2021, study 1). Several of the descriptions of these arguments can be categorised in accordance with the ideological dilemmas identified in the present article. First, "children bring individual happiness 
and love, a purpose to life" versus "having kids is selfish/irresponsible" represent dilemmatic aspects of liberalism. Second, "society needs young people" versus "resources are overused" represent dilemmatic aspects of sustainable development. Third, "Global North versus Global South" versus "compensate for not having children by adopting" represent dilemmatic aspects of globalism. Fourth, "human nature may be to reproduce" and "racial divides" versus "the best course of action on an individual's carbon footprint" represent dilemmatic aspects of biologism. Fifth, "provide an opportunity to educate and bring up children to change the world" versus "kids are likely to have a worse outlook on life" represent dilemmatic aspects of humanism.

Furthermore, Rieder (2016) discussed the morality of procreation in light of overpopulation and climate change. Relating to the ideological dilemmas presented here, his arguments particularly represent the dilemmatic aspects of liberalism, with the conflict between individual responsibility and individual freedom. He attempts to resolve the dilemma by concluding that while not having children is the most defendable course of action, restricting oneself to having one child might be acceptable from a moral and environmental point of view.

Even though the choice of living environmentally childfree seems like a controversial topic, the conflicts and processes described here are not unique for this type of pro-environmental behaviour. The ideological concept of sustainable development is especially present in other areas as well, for instance in debates over the use of fees and taxes in shaping pro-environmental behaviour, where the socioeconomic (i.e. inequality issues) and ecological (i.e. reduced environmental impact) dimensions represent opposing positions. In Norway, the government's use of road tolls illustrates such a debate (NRK, 2019). Furthermore, debates often split the ecological dimension between concern for the climate and concern for the environment and biological diversity. In Norway, this is illustrated by debates where climate-friendly, renewable energy solutions such as windmills are opposed because of their negative effects on the environment and biological diversity (Hågvar, 2016).

The tension seen between ecological sustainability and social and economic sustainability when it comes to the question of reproduction is perhaps analogous to the tension between Norway's role as an ambitious climate leader on the one hand and its status as a major petroleum and gas producer on the other (Eckersley, 2016). Furthermore, the discursive handling of this tension has similarities with how the ideological concept of sustainable development opposes the idea of living environmentally childfree. One discourse emphasises Norway's international responsibility in addressing the twin challenge of poverty and climate change (i.e. globalism), while another emphasises Norway's history as a technological pioneer through a story of industrialisation and modernisation (i.e. economic and social sustainable development).

The ideological dilemmas analysed and discussed here present parts of the explanation concerning why we do not tie reproductive choices to the mitigation of the environmental crises, as evident in the study where only 53 of 4634 responses suggested climate change solutions related to reproduction and population (Tvinnereim et al., 2017). The main reason for this disconnection seems to be that the opposing themes within both liberalism, sustainable development, globalism, biologism, and humanism include arguments of such character that they shift the topic or frame living environmentally childfree as irrelevant.

Furthermore, this explanation might say something about how we generally relate to solutions to the ongoing climatic and environmental crises, where it seems like our responses are based on adjustments rather than fundamental changes like planning for smaller families. The preference for adjustments rather than fundamental changes is evident in the Norwegian government's climate action plan for 2021-2030, where a 
stepwise increase in carbon taxes is the main solution (Norwegian Ministry of Climate \& Environment, 2021). Furthermore, the use of renewable energy in the extraction of oil and gas is presented as an important action for the reduction of Norway's emission of greenhouse gases (Bru, 2020).

Again, Norway's role as a major petroleum and gas producer serves as an analogy: Rather than closing down the petroleum sector or viewing reproduction as part of the picture, we try to produce our oil as cleanly as possible and raise our children as environmentally friendly as possible.

\section{Limitations}

The main limitation of this study concerns the scope of the material and the analytic approach. A rather large amount of material consisting of 31 items was analysed using a synthesis of critical discursive psychology and thematic analysis. A smaller amount of material and a different analytic approach would probably have given other results. For instance, a conversation analysis based on just the radio and TV programmes with live interaction could have given a better picture of how, for example, whataboutery is used in these debates.

Furthermore, the search for relevant items did not follow any systematic procedure. A more stringent use of inclusion criteria regarding both search terms and type of media would probably have resulted in a different and perhaps more representative material. Similarly, the identification of ideological dilemmas through an analytical cycle between themes and material did not follow any predetermined steps, which may have weakened the reliability of the analysis.

Finally, this study is limited by the lack of religious perspectives on a topic that many people relate to religion. One of the debates in the material included a politician from a Christian political party (NRK, 2017b), but she did not make any reference to religion. An opinion did discuss how the link between reproduction and environment is not welcomed by the Catholic Church (Alstadheim, 2018). Nonetheless, overall, this study failed to identify relevant dilemmatic religious perspectives in the Norwegian context. Similarly, the analysis failed to find dilemmatic aspects of feminism, thereby grouping the identified feminist positions into other ideological concepts.

\section{Future Research}

Future research could address both limitations mentioned above: first, by looking closer at how conversations and debates on the topic develop and second by attempting to investigate how religions and religious people position themselves on the question of living environmentally childfree.

Furthermore, research might also look more explicitly at how politicians and organisations in general relate to the topic, as politicians and organisations in the present material seemed eager to discuss issues other than living environmentally childfree. The questions of reproduction and environmental crises are too important to be avoided by political and organisational leaders.

Moreover, research could apply a social representations framework (e.g. Moscovici, 1988) to investigate how the media coverage and ideological dilemmas of living environmentally childfree are not just reflections of people's attitudes and views, but also constitute social representations that contribute to constructing new meaning and thus might 
have an impact on individuals' own thoughts and decisions. Similarly, cultural psychology's emphasis on dynamic meaning-making through the use of sign systems at various levels, such as personal, societal or political (Valsiner, 2019), could be valuable in exploring how debates and conversations on the topic of living environmentally childfree might have an impact at the personal level.

Finally, future research on the topic should take into account not only the possible racist connotations addressed in the present article but also feminist, intersectional perspectives that try to identify manifestations of population control in the present discourse (Bhatia et al., 2020).

\section{Conclusion}

The analysis identified five ideological concepts with ideological dilemmas: liberalism, sustainable development, globalism, biologism and humanism. Each of these concepts contains positions supporting and opposing the idea of living environmentally childfree in Norway. A possible consequence of the dilemmas is that the perceived relevance of living environmentally childfree is weakened through, for instance, whataboutery and the tension between the different components of sustainable development.

Society's view on living environmentally childfree might reflect how we generally understand solutions to the environmental crises. More specifically, it seems like we have a preference for solutions that do not challenge our assumptions about what a good and meaningful life is, and that do not demand too big changes to our incorporated ideas about society. As an example of a solution that would challenge such assumptions and ideas, some researchers have argued that fertility reductions should be supplemented with facilitation of emigration from developing nations to developed nations, allowing for both global reductions in ecological impact and continued economic stability (Earl et al., 2017).

Instead of engaging in such radical proposals, the idea of living environmentally childfree is framed as irrelevant through the ideological processes described in this article. This could perhaps be understood as a form of "implicatory denial" (Washington \& Cook, 2011, p. 98), in which climate change information and its interpretations are both accepted, while the psychological, political or moral implications are denied. In other words, implicatory denial of the idea of living environmentally childfree could include an acceptance of the magnitude of the problems but not the magnitude of the solutions needed to solve them.

\section{Appendix}

All translated quotes ordered chronologically after their appearance in the article.

\begin{tabular}{lll}
\hline Original quote & Translated quote & Reference \\
\hline "Klimapolitikken vil aldri bli betre & "The climate policy will never be & Norwegian Ministry of Climate \\
enn summen av frie val frå & better than the sum of free choices & and Environment (2021, p. \\
millionar av menneske" & from millions of humans" & 14) \\
\hline
\end{tabular}




\begin{tabular}{|c|c|c|}
\hline Original quote & Translated quote & Reference \\
\hline $\begin{array}{l}\text { "Ofte reagerer folk med å si at det } \\
\text { å få barn er noe veldig personlig } \\
\text { og intimt som ingen andre skal } \\
\text { kunne si noe på, men i prinsippet } \\
\text { er argumentet akkurat det same } \\
\text { som det vi bruker overfor dem } \\
\text { som flyr mye: Ikke gjør det, det } \\
\varnothing \text { delegger for Jorden og for andre" }\end{array}$ & $\begin{array}{l}\text { "People often react by saying that } \\
\text { having children is something very } \\
\text { private and intimate that no one } \\
\text { else should have a say in, but in } \\
\text { principle the argument is just the } \\
\text { same as we use against those who } \\
\text { fly a lot: Don't do it, it destroys } \\
\text { for the Earth and for others" }\end{array}$ & Salvesen (2016, para. 19) \\
\hline $\begin{array}{l}\text { "Uansett har utdanning og } \\
\text { velstandsutvikling vist seg langt } \\
\text { mer vellykket for å begrense } \\
\text { befolkningsvekst enn ulike former } \\
\text { for menneskerettighetsbrudd" }\end{array}$ & $\begin{array}{l}\text { "Education and welfare have } \\
\text { nonetheless proved way more } \\
\text { successful at limiting population } \\
\text { growth, compared to different } \\
\text { forms of violations of human } \\
\text { rights" }\end{array}$ & Aftenposten (2020, para. 7) \\
\hline $\begin{array}{l}\text { "Og det er kjent at } \\
\text { overbefolkning, vi er } 8 \text { milliarder, } \\
\text { og at dette skaper et enormt } \\
\text { miljøproblem. Og alle tall er røde, } \\
\text { (...) ikke bare på } \mathrm{CO}_{2} \text {-utslipp, jeg } \\
\text { tenker på forurensning, på } \\
\text { veibygging, på alt mulig" }\end{array}$ & $\begin{array}{l}\text { "And it is known that } \\
\text { overpopulation, we are } 8 \text { billion, } \\
\text { creates a huge environmental } \\
\text { problem. And all numbers are } \\
\text { red, (...) not just } \mathrm{CO}_{2} \text { emissions, I } \\
\text { think about pollution, road } \\
\text { building, everything" }\end{array}$ & NRK (2017a) \\
\hline $\begin{array}{l}\text { "Hvis vi ender opp med samme } \\
\text { type tilstand som det er i land som } \\
\text { for eksempel Italia og Japan, så } \\
\text { får du en sosial dynamikk som er } \\
\text { veldig uheldig, og som gjør det } \\
\text { vanskelig å løse andre } \\
\text { samfunnsproblemer" }\end{array}$ & $\begin{array}{l}\text { "If we end up with the same type of } \\
\text { situation as in countries like Italy } \\
\text { and Japan, then you get a social } \\
\text { dynamic that is very unfortunate, } \\
\text { and which makes it difficult to } \\
\text { solve other societal issues" }\end{array}$ & NRK (2017a) \\
\hline $\begin{array}{l}\text { "Ettbarnspolitikk blir nødvendig } \\
\text { i den vestlige delen av verden } \\
\text { for å få ned forbruket og kunne } \\
\text { redde kloden. For det er vi som } \\
\text { forbruker mest. Vi forbruker cirka } \\
200 \text { ganger mer per individ enn en } \\
\text { nigerianer, ikke sant" }\end{array}$ & $\begin{array}{l}\text { "One-child policy will become } \\
\text { necessary in the western part } \\
\text { of the world in order to reduce } \\
\text { consumption and be able to save } \\
\text { the globe. Because we consume } \\
\text { the most. We consume about } \\
200 \text { times more per capita than a } \\
\text { Nigerian, you know" }\end{array}$ & Holth (2018, para. 21) \\
\hline $\begin{array}{l}\text { "Nøkkelen til det her er at kvinners } \\
\text { rettigheter, kvinners utdanning og } \\
\text { kvinners yrkesdeltakelse løftes } \\
\text { opp, det er derfor vi i MDG } \\
\text { støtter Malala og alle andre som } \\
\text { jobber for kvinners rett til } \\
\text { utdanning. Det er det mest } \\
\text { effektive grepet, sammen med } \\
\text { familieplanlegging, vi kan gjøre, } \\
\text { for å få dette her til å bli bedre liv } \\
\text { i bedre byer i fremtiden" }\end{array}$ & $\begin{array}{l}\text { "The key here is that women's } \\
\text { rights, women's education and } \\
\text { women's employment are lifted, } \\
\text { that is way we in the Green Party } \\
\text { support Malala and all others who } \\
\text { work for women's right to } \\
\text { education. That is the most } \\
\text { efficient measure we can take, } \\
\text { along with family planning, in } \\
\text { order for this to become better } \\
\text { lives in better cities in the future" }\end{array}$ & NRK (2017b) \\
\hline $\begin{array}{l}\text { "Og det eneste som er viktig her, } \\
\text { egentlig, er denne søyla her: Som } \\
\text { viser utslippsreduksjon, eller } \\
\text { klimagassreduksjon, hvis du har } \\
\text { ett mindre barn. Så dette er altså } \\
60 \text { tonn, mens du kan } \\
\text { sammenligne med resirkulering } \\
\text { som er på } 0,21 "\end{array}$ & $\begin{array}{l}\text { "And the only thing that matters } \\
\text { here, really, is this column: It } \\
\text { shows reduced emissions, or } \\
\text { climate gas reductions, when you } \\
\text { have one fewer child. So this is } \\
60 \text { metric tons, which you can } \\
\text { compare to recycling at } 0.21 "\end{array}$ & NRK (2017d) \\
\hline
\end{tabular}




\begin{tabular}{|c|c|c|}
\hline Original quote & Translated quote & Reference \\
\hline $\begin{array}{l}\text { "Jeg tror det er usannsynlig at det å } \\
\text { ikke ha barn skal være det } \\
\text { prisverdige, mens å ha ett barn } \\
\text { skulle være klanderverdig. Det } \\
\text { ligger ganske tett på den } \\
\text { menneskelige natur å få barn, } \\
\text { så det er vanskelig å se for seg i } \\
\text { praksis, at det skulle gå så langt, } \\
\text { tror jeg" }\end{array}$ & $\begin{array}{l}\text { "I think it is unlikely that not having } \\
\text { children will become } \\
\text { praiseworthy, while having one } \\
\text { child is reprehensible. It is quite } \\
\text { tied to the human nature to have } \\
\text { children, so it is difficult to } \\
\text { imagine in practice, that it could } \\
\text { go that far, I think" }\end{array}$ & NRK (2020b) \\
\hline $\begin{array}{l}\text { “Sigve Tjøtta presterer å antyde at } \\
\text { ønsket om å begrense } \\
\text { befolkningsveksten er inhumant. } \\
\text { Hva er inhumant ved å ville unngå } \\
\text { Malthus' verste } \\
\text { fremtidsscenarier? (...) Det } \\
\text { handler jo ikke om at de barna } \\
\text { som faktisk blir satt til verden, } \\
\text { skal mottas med mindre } \\
\text { kjærlighet. Tvert imot, det handler } \\
\text { om å ta disse barnas fremtid på } \\
\text { alvor" }\end{array}$ & $\begin{array}{l}\text { "Sigve Tjøtta manages to imply that } \\
\text { the wish to reduce } \\
\text { population growth is inhumane. } \\
\text { What is inhumane about } \\
\text { wanting to avoid Malthus' worst } \\
\text { scenarios? (...) It is not about not } \\
\text { giving love to the children who } \\
\text { actually are born. On the contrary, } \\
\text { it is about taking these children's } \\
\text { future seriously" }\end{array}$ & Sandvik (2013, para. 5-6) \\
\hline $\begin{array}{l}\text { “Okay, gitt at vi ønsker å ha } \\
\text { meningsfulle liv, og vi ønsker å } \\
\text { ha gode samfunn, hvordan gjør } \\
\text { vi det på en måte som ikke går } \\
\text { utover fremtidige generasjoner og } \\
\text { det livsgrunnlaget vi har til felles. } \\
\text { Og derfor vil jo de fleste av oss } \\
\text { politikere være opptatt av hvordan } \\
\text { kan man bruke de mulighetene } \\
\text { vi har innenfor ramma. Vi ønsker } \\
\text { gode liv, med samfunn hvor man } \\
\text { kan få barn og oppleve } \\
\text { meningsfullhet” }\end{array}$ & $\begin{array}{l}\text { "Okay, given that we seek } \\
\text { meaningful lives, and good } \\
\text { societies, how do we do that in } \\
\text { a way which does not take away } \\
\text { from future generations and our } \\
\text { common basis of life. } \\
\text { Therefore most of us politicians } \\
\text { are concerned with how we can } \\
\text { use the possibilities we have } \\
\text { within our limits. We want good } \\
\text { lives, with societies where one } \\
\text { can have children and experience } \\
\text { meaningfulness" }\end{array}$ & NRK (2017d) \\
\hline $\begin{array}{l}\text { "Men selv om vi går med på ideen } \\
\text { om at det å få barn skal vurderes } \\
\text { på samme måte som å ta et fly til } \\
\text { Bali, er det et langt mer } \\
\text { grunnleggende spørsmål som er } \\
\text { igjen: Kan du som enkeltperson } \\
\text { i det hele tatt gjøre noe for å } \\
\text { motvirke klimaendringer? Har } \\
\text { det noe å si, i det store bildet, om } \\
\text { du velger å leve et barnløst eller } \\
\text { billøst liv?” }\end{array}$ & $\begin{array}{l}\text { "Even if we accept the idea that } \\
\text { having children should be } \\
\text { assessed in the same way as flying } \\
\text { to Bali, we are still left with a far } \\
\text { more fundamental question: Can } \\
\text { you, as an individual, do anything } \\
\text { at all to mitigate climate change? } \\
\text { Does it matter, in the big picture, } \\
\text { whether you choose to live a } \\
\text { childfree or car-free life?" }\end{array}$ & Parmentier (2018, para. 4) \\
\hline $\begin{array}{l}\text { "Tanken på at ressurser og } \\
\text { økologien er begrenset, tror jeg } \\
\text { ligger naturlig for oss mennesker. } \\
\text { Alt vi liker, ønsker og trenger er } \\
\text { begrenset på kort sikt. Men det er } \\
\text { annen side av mennesker som det } \\
\text { kanskje er lett å overse. } \\
\text { Mennesker er produktive, } \\
\text { innovative og kreative, og kan } \\
\text { skape en bedre verden på lengre } \\
\text { sikt" }\end{array}$ & $\begin{array}{l}\text { "I believe it is in our nature to think } \\
\text { that resources and the ecology is } \\
\text { limited. Everything we like, want } \\
\text { and need is limited in the short } \\
\text { term. However, there is another } \\
\text { side of our nature that might be } \\
\text { easily overlooked: Humans are } \\
\text { productive, innovative and } \\
\text { creative, and are able to create a } \\
\text { better world in the long term" }\end{array}$ & Tjøtta (2013, para. 3) \\
\hline
\end{tabular}




\begin{tabular}{|c|c|c|}
\hline Original quote & Translated quote & Reference \\
\hline $\begin{array}{l}\text { "Problemet er bare at business as } \\
\text { usual mangler enhver fysisk, } \\
\text { matematisk, økologisk, } \\
\text { geografisk, demografisk og } \\
\text { klimatisk realisme" }\end{array}$ & $\begin{array}{l}\text { "The problem is that business as } \\
\text { usual lack any physical, } \\
\text { mathematic, ecological, } \\
\text { geographic, demographic and } \\
\text { climatic realism" }\end{array}$ & Sandvik (2013, para. 1) \\
\hline $\begin{array}{l}\text { "Og et av de viktigste tiltakene jeg } \\
\text { kan tenke meg da, ved siden av } \\
\text { utdanning av unge i u-land, og } \\
\text { ved siden av å hjelpe kvinner med } \\
\text { bedre helse og reproduktiv helse, } \\
\text { er å få ned antallet barn i den rike } \\
\text { verden" }\end{array}$ & $\begin{array}{l}\text { "One of the most important } \\
\text { measures I can imagine, then, } \\
\text { besides educating young people in } \\
\text { developing countries, and besides } \\
\text { helping women with better health } \\
\text { and reproductive health, is to } \\
\text { reduce the number of children in } \\
\text { the rich part of the world" }\end{array}$ & NRK (2017c) \\
\hline $\begin{array}{l}\text { “A: Effekten av å få et barn mindre, } \\
\text { er altså } 25 \text { ganger større enn å } \\
\text { leve bilfritt, hvis vi skal ta et } \\
\text { klimaregnskap. (...) }\end{array}$ & $\begin{array}{l}\text { "A: The effect of having one child } \\
\text { less, is } 25 \text { times bigger than the } \\
\text { effect of living car-free, when } \\
\text { looking at the climate impact. }\end{array}$ & NRK (2017b) \\
\hline $\begin{array}{l}\text { B: I Norge er ikke det her noe } \\
\text { problem. Vi har en fruktbarhet } \\
\text { i Norge på } 1,7 \text { barn per kvinne. } \\
(\ldots)\end{array}$ & $\begin{array}{l}\text { B: In Norway, this is not a problem. } \\
\text { We have a fertility rate at } 1.7 \\
\text { children per woman. }(\ldots)\end{array}$ & \\
\hline $\begin{array}{l}\text { C: Man vet at i en del land i Afrika } \\
\text { så er bortimot } 70 \text { prosent av alle } \\
\text { jentene bortgiftet før de er } 18 \text { år, } \\
\text { og får gjerne to barn før de blir } \\
18 \text { år. }(. .)\end{array}$ & $\begin{array}{l}\text { C: We know that in some African } \\
\text { countries almost } 70 \text { percent of all } \\
\text { girls are married before they turn } \\
18 \text { years, and will likely have two } \\
\text { children before turning } 18 .(\ldots)\end{array}$ & \\
\hline $\begin{array}{l}\text { D: Nå har vi jo sagt flere av oss at i } \\
\text { Norge har vi } 1,7 \text { barn per kvinne, } \\
\text { og hvis en ser fremover så er ikke } \\
\text { det heller bæredyktig, i hvert fall } \\
\text { ikke for å opprettholde de } \\
\text { velferdsordningene vi har i dag. } \\
\text { (...) }\end{array}$ & $\begin{array}{l}\text { D: Several of us have said that } \\
\text { Norway now has } 1.7 \text { children } \\
\text { per woman, and looking into the } \\
\text { future, that is not sustainable } \\
\text { either, especially regarding the } \\
\text { welfare programmes we have } \\
\text { today. (...) }\end{array}$ & \\
\hline $\begin{array}{l}\text { C: Jeg hørte Kenya ble nevnt her i } \\
\text { sted, de har de siste } 60 \text { årene } \varnothing \mathrm{kt} \\
\text { fra } 7 \text { millioner til } 49 \text { millioner } \\
\text { innbyggere. Selvfølgelig skaper } \\
\text { det problemer. (...) }\end{array}$ & $\begin{array}{l}\text { C: I heard Kenya was mentioned } \\
\text { earlier, the last } 60 \text { years they have } \\
\text { increased from a population of } \\
7 \text { million to a population of } 49 \\
\text { million. Of course that creates }\end{array}$ & \\
\hline $\begin{array}{l}\text { B: Der hvor [C] gjør det litt for } \\
\text { lettvint, er ved å si at det er } \\
\text { kun antallet som teller. Vi har } \\
\text { for eksempel } 3000 \text { milliarder } \\
\text { trær i verden, men det er ikke } \\
\text { overbefolkning av trær. Vi har } 10 \\
000 \text { millioner, milliarder maur i } \\
\text { verden, men det er ikke } \\
\text { overbefolkning av maur } \\
\text { A: De forbruker jo mindre enn oss" }\end{array}$ & $\begin{array}{l}\text { problems. }(\ldots) \\
\text { B: Where [C] makes it too easy } \\
\text { for himself, is by saying that just } \\
\text { quantity matters. We for instance } \\
\text { have } 3000 \text { billion trees in the } \\
\text { world, but there is no } \\
\text { overpopulation of trees. We have } \\
10000 \text { million, billion ants in the } \\
\text { world, but there is no } \\
\text { overpopulation of ants } \\
\text { A: They do consume less than we } \\
\text { do" }\end{array}$ & \\
\hline $\begin{array}{l}\text { "Om overbefolkning er et } \\
\text { problem? Du kan si det sånn at } \\
\text { alle miljøproblemene våre hadde } \\
\text { vært mindre hvis vi hadde vært } \\
\text { færre folk" }\end{array}$ & $\begin{array}{l}\text { "If overpopulation is a problem? } \\
\text { You can say that all our } \\
\text { environmental problems would } \\
\text { have been smaller if we were } \\
\text { fewer people" }\end{array}$ & Salvesen (2016, para. 67) \\
\hline
\end{tabular}


Acknowledgements The author thanks Ole Jacob Madsen for supervision and feedback.

Funding Open access funding provided by University of Oslo (incl Oslo University Hospital).

\section{Declarations}

Competing Interests The author declares no competing interests.

Open Access This article is licensed under a Creative Commons Attribution 4.0 International License, which permits use, sharing, adaptation, distribution and reproduction in any medium or format, as long as you give appropriate credit to the original author(s) and the source, provide a link to the Creative Commons licence, and indicate if changes were made. The images or other third party material in this article are included in the article's Creative Commons licence, unless indicated otherwise in a credit line to the material. If material is not included in the article's Creative Commons licence and your intended use is not permitted by statutory regulation or exceeds the permitted use, you will need to obtain permission directly from the copyright holder. To view a copy of this licence, visit http://creativecommons.org/licenses/by/4.0/.

\section{References}

Aftenposten. (2020). Overbefolkning blir neppe noe stort problem [Editorial]. https://www.aftenposten. no/meninger/leder/i/2GL1EB/aftenposten-mener-overbefolkning-blir-neppe-noe-stort-problem

Alstadheim, K. B. (2018). Bekymret for klima? Gi alle jenter skolegang. Dagens Naringsliv. https:// www.dn.no/uten-filter/klima/befolkningsvekst/utdannelse/bekymret-for-klima-gi-alle-jenterskolegang/2-1-500548

Andersen, E. (2021). Decline in fertility. Statistics Norway. https://www.ssb.no/en/befolkning/artiklerog-publikasjoner/decline-in-fertility--448107

Andersen, M. G. (2020). “Jeg må ikke ha barn i livet mitt for at livet skal gi mening”. En kvalitativ undersфkelse om barnfrihet blant menn og kvinner i Norge [Unpublished master's thesis]. University of Bergen, Norway. https://hdl.handle.net/1956/23117

Andrijevic, M., \& Striessnig, E. (2017). Less feet, less footprint: the relationship between environmental concern and fertility intentions. Poster session presented at the 2017 International Population Conference in Cape Town, South Africa. https://iussp.confex.com/iussp/ipc2017/meetingapp.cgi/Paper/ 6509

Arnocky, S., Dupuis, D., \& Stroink, M. L. (2012). Environmental concern and fertility intentions among Canadian university students. Population and Environment, 34, 279-292. https://doi.org/10.1007/ s11111-011-0164-y

Aufrecht, M. (2012). Rethinking "greening of hate": Climate emissions, immigration, and the last frontier. Ethics and the Environment, 17(2), 51-74. https://doi.org/10.2979/ethicsenviro.17.2.51

Bahn, M. (2019). Virkelighet i vannliljer. Klassekampen. https://klassekampen.no/utgave/2019-08-16/ virkelighet-i-vannliljer

Bhatia, R. (2004). Green or brown? White nativist environmental movements. In A. L. Ferber (Ed.), Homegrown Hate. Gender and Organized Racism (pp. 194-214). New York: Routledge.

Bhatia, R., Sasser, J. S., Ojeda, D., Hendrixson, A., Nadimpally, S., \& Foley, E. E. (2020). A feminist exploration of 'populationism': Engaging contemporary forms of population control. Gender, Place \& Culture, 27(3), 333-350. https://doi.org/10.1080/0966369X.2018.1553859

Billig, M., Condor, S., Edwards, D., Gane, M., Middleton, D., \& Radley, A. (1988). Ideological dilemmas: A social psychology of everyday thinking. London: Sage Publications Inc.

Bjertnæs, G. H. M., Holmøy, E., \& Strøm, B. (2019). Rapporter 2019/16. Langsiktige virkninger på offentlige finanser og verdiskapning av endringer $i$ fruktbarhet. Statistics Norway. https://www.ssb.no/ nasjonalregnskap-og-konjunkturer/artikler-og-publikasjoner/langsiktige-virkninger-pa-offentligefinanser-og-verdiskapning-av-endringer-i-fruktbarhet

Braun, V., \& Clarke, V. (2006). Using thematic analysis in psychology. Qualitative Research in Psychology, 3(2), 77-101. https://doi.org/10.1191/1478088706qp063oa

Brovold, C. H. (2020). Rapporter 2020/20. Økonomisk integrering for innvandrere over tid. Statistics Norway. https://www.ssb.no/inntekt-og-forbruk/artikler-og-publikasjoner/okonomisk-integrering-forinnvandrere-over-tid 
Browne, K. (2005). Snowball sampling: Using social networks to research non-heterosexual women. International Journal of Social Research Methodology: Theory \& Practice, 8(1), 47-60. https://doi.org/10. $1080 / 1364557032000081663$

Bru, T. (2020). Mer elektrifisering er fremtiden—også offshore. Stavanger Aftenblad. https://www.aftenbladet. no/meninger/debatt/i/Qmgdy8/mer-elektrifisering-er-fremtiden-ogsaa-offshore

Comolli, C. L., Neyer, G., Andersson, G., Dommermuth, L., Fallesen, P., Jalovaara, M., Klængur Jónsson, A., Kolk, M., \& Lappegård, T. (2020). Beyond the economic gaze: Childbearing during and after recessions in the Nordic countries. European Journal of Population, 37, 473-520. https://doi.org/10.1007/ s10680-020-09570-0

Cools, S., \& Strøm, M. (2020). Rapport 2020:5. Ønsker om barn-en spфrreunders $\phi k e l s e$ om fertilitet, arbeidsliv og familiepolitikk. Institute for Social Research. https://hdl.handle.net/11250/2645776

Daily, G. C., Ehrlich, A. H., \& Ehrlich, P. R. (1994). Optimum human population size. Population and Environment, 15(6), 469-475. http://www.jstor.org/stable/27503368

Davis, A. C., Arnocky, S., \& Stroink, M. (2019). The problem of overpopulation: Proenvironmental concerns and behavior predict reproductive attitudes. Ecopsychology, 11(2), 92-100. https://doi.org/10. 1089/eco.2018.0068

Earl, J., Hickey, C., \& Rieder, T. N. (2017). Fertility, immigration, and the fight against climate change. Bioethics, 31(8), 582-589. https://doi.org/10.1111/bioe.12374

Eckersley, R. (2016). National identities, international roles, and the legitimation of climate leadership: Germany and Norway compared. Environmental Politics, 25(1), 180-201. https://doi.org/10.1080/09644016. 2015.1076278

Ellingsæter, A. L., (2012). Barn i politikkens sentrum—pronatalisme på norsk. Nytt Norsk Tidsskrift, 29(4), 361-371. https://www.idunn.no/nnt/2012/04/barn_i_politikkens_sentrum_-_pronatalisme_p_norsk

Fjell, T. I. (2008). A si nei til meningen med livet? En kulturvitenskapelig analyse av barnfrihet. Trondheim: Tapir akademisk forlag.

Fleming, A. (2018). Would you give up having children to save the planet? Meet the couples who have. The Guardian. https://www.theguardian.com/world/2018/jun/20/give-up-having-children-couples-saveplanet-climate-crisis

Gaviola, A. (2019). Canadian teens are pledging not to have children to fight climate change. Vice. https://www. vice.com/en_ca/article/43ka5n/canadian-teens-are-pledging-not-to-have-children-to-fight-climate-change

Greve, B., Blomquist, P., Hvinden, B., \& van Gerven, M. (2021). Nordic welfare states-still standing or changed by the COVID-19 crisis? Social Policy \& Administration, 55(2), 295-311. https://doi.org/10. $1111 /$ spol.12675

Hamity, M., Dillard, C., Bexell, S. M., \& Graff-Hughey, C. (2019). A human rights approach to planning families. Social Change, 49(3), 469-492. https://doi.org/10.1177/0049085719863894

Harris, J. M. (2001). Basic principles of sustainable development. In K. S. Bawa \& R. Seidler (Eds.), Encyclopedia of Life Support Systems: Dimensions of Sustainable Development (volume 1) (pp. 21-40). United Nations Educational, Scientific, and Cultural Organization.

Hauglid, E. (2016). Flere bier er bra, men færre folk er best. Morgenbladet. https://morgenbladet.no/aktuelt/ 2016/07/espen-hauglid-om-bier-i-byen

Helm, S., Kemper, J., \& White, S. (2021). No future, no kids-no kids, no future? Population and Environment, 43, 108-129. https://doi.org/10.1007/s11111-021-00379-5

Henriksen, J. (2019). "Grønn vekst" er umulig. Morgenbladet. https://morgenbladet.no/ideer/2019/05/ gronn-vekst-er-umulig

Hofstede, G. (2001). Culture's consequences: Comparing values, behaviors, institutions, and organizations across nations (2nd ed.). Thousand Oaks, CA: Sage.

Holth, O. Ø. S. (2018). Grønnskollingen. Dagens Naringsliv. https://www.dn.no/magasinet/portrettet/ gert-nygardshaug/litteratur/klimapolitikk/-jeg-ser-jo-at-ettbarnspolitikk-blir-nodvendig-i-den-vestligedelen-av-verden/2-1-390478

Humberset, K., \& Langset, K. G. (2018, August 22). Magnhild (31) vurderer å forbli barnløs: Er det bra for miljøet å få barn? Aftenposten. https://www.aftenposten.no/foreldreliv/i/LA32v9/magnhild-31-vurdereraa-forbli-barnloes-boer-jeg-ha-daarlig-miljoesamv

Hunt, E. (2019). BirthStrikers: meet the women who refuse to have children until climate change ends. The Guardian. https:/www.theguardian.com/lifeandstyle/2019/mar/12/birthstrikers-meet-the-women-whorefuse-to-have-children-until-climate-change-ends

Hågvar, S. (2016). Åtte argumenter mot naturødeleggende vindkraft. Aftenposten. https://www.aftenposten. no/meninger/debatt/i/1 knyq/aatte-argumenter-mot-naturoedeleggende-vindkraft-sigmund-haagvar

Ibsen, A. Z. (2019). Vi ser en ny grønnbrun bevegelse på nettet. Morgenbladet. https://morgenbladet.no/ ideer/2019/08/vi-ser-en-ny-gronnbrun-bevegelse-pa-nettet-skriver-alexander-zlatanos-ibsen 
Innset, O. (2020). En råtten avokado. Klassekampen. https://klassekampen.no/utgave/2020-01-28/en-rattenavokado

Jødal, M. (2013). Er klokka to på tolv? Morgenbladet. https://morgenbladet.no/debatt/2013/er_klokka_to_ pa_tolv

Kolstad, A., \& Horpestad, S. (2009). Self-construal in Chile and Norway: Implications for cultural differences in individualism and collectivism. Journal of Cross-Cultural Psychology, 40(2), 275-281. https://doi.org/10.1177/0022022108328917

Kristensen, G. K. (2020). Offentlige samtaler om fruktbarhet i dagens Norge. Mellom nasjonal velferdsstatskrise og global klimakrise. Tidsskrift for kjфnnsforskning, 44(2), 152-165. https://doi.org/10.18261/ issn.1891-1781-2020-02-05

Kristiansen, B. S. (2018). Frp-topp: Folk med dårlig råd bør få færre barn. Dagsavisen. https://www. dagsavisen.no/nyheter/innenriks/frp-topp-folk-med-darlig-rad-bor-fa-ferre-barn-1.1128743

Lie, E. (2018). Learning by failing. The origins of the Norwegian Oil Fund. Scandinavian Journal of History, 43(2), 284-299. https://doi.org/10.1080/03468755.2018.1430657

Malthus, T. (1798). An essay on the principle of population. London: J. Johnson. https://www.gutenberg. org/ebooks/4239

Martiniussen, E. (2013). Tåkefyrsten Randers. Morgenbladet. https://morgenbladet.no/debatt/2013/takefyrsten_ randers

Mathismoen, O. (2018). Klimapanelet «glemte» å si én ting: Befolkningsveksten må stoppe for at vi skal nå FNs klimamål. Aftenposten. https://www.aftenposten.no/viten/i/Qlz6bx/klimapanelet-glemte-aa-si-enting-befolkningsveksten-maa-stoppe-for-a

Mayhew, S. H., Newman, K., Johnson, D., Clark, E., Hammer, M., Mohan, V., \& Ssali, S. (2020). New partnerships, new perspectives: The relevance of sexual and reproductive health and rights for sustainable development. Health Policy, 124(6), 599-604. https://doi.org/10.1016/j.healthpol.2019.03. 010

Moscovici, S. (1988). Notes towards a description of social representations. European Journal of Social Psychology, 18(3), 211-250. https://doi.org/10.1002/ejsp.2420180303

Murtaugh, P. A., \& Schlax, M. G. (2009). Reproduction and the carbon legacies of individuals. Global Environmental Change, 19(1), 14-20. https://doi.org/10.1016/j.gloenvcha.2008.10.007

Nafstad, H. E., \& Blakar, R. M. (Eds.). (2009). Fellesskap og individualisme. Oslo: Gyldendal akademisk.

Nakkerud, E. (2021). There are many people like me, who feel they want to do something bigger": An exploratory study of choosing not to have children based on environmental concerns. Ecopsychology, 13(3), 200-209. https://doi.org/10.1089/eco.2020.0057

Nielsen, E. G. (2018). Ettbarnspolitikk for miljøet? Dagens Naringsliv. https://www.dn.no/innlegg/ miljo/befolkningsvekst/gert-nygardshaug/ettbarnspolitikk-for-miljoet/2-1-395296

Norwegian Ministry of Climate and Environment. (2021). Meld. St. 13 (2020-2021): Klimaplan for 2021-2030. https://www.regjeringen.no/contentassets/a78ecf5ad2344fa5ae4a394412ef8975/nn-no/ pdfs/stm202020210013000dddpdfs.pdf

NRK. (2017a). Bør det bli færre nordmenn? [Radio programme]. In Verdibørsen. https://radio.nrk.no/ podkast/verdiboersen/sesong/201705/1_2b6c6d20-9e92-469f-ac6d-209e92e69ff2

NRK. (2017b). Barn dårlig for klima [TV programme]. In Dagsnytt 18. https://tv.nrk.no/serie/dagsnyttatten-tv/201709/NNFA56090117

NRK. (2017c). Er overbefolkning et problem? [Radio programme]. In Verdibørsen. https://radio.nrk.no/ serie/verdiboersen/sesong/201709/mkrv17015317

NRK. (2017d). Søppelproblember [TV programme]. In Debatten. https://tv.nrk.no/serie/debatten/ 201709/NNFA51092117

NRK. (2019). Bompenger [TV programme]. In Debatten. https://tv.nrk.no/serie/debatten/201905/ NNFA51050919

NRK. (2020a). Er færre mennesker på jorda en gladsak? [Radio programme]. In Verdibørsen. https:// radio.nrk.no/podkast/verdiboersen/sesong/202008/1_fa150c64-b97e-40fb-950c-64b97ef0fb70

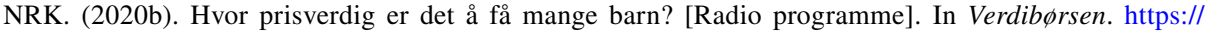
radio.nrk.no/podkast/verdiboersen/sesong/202010/1_bbf1eb5b-648b-47d1-b1eb-5b648b67d155

O’Connell, E. (2021). Whataboutery. International Journal of Applied Philosophy, 34(2), 243-254. https://doi.org/10.5840/ijap2021329148

Parmentier, F.-J. (2018). Redd barna. Klassekampen. https://klassekampen.no/utgave/2018-12-28/ redd-barna

Rieder, T. N. (2016). Toward a small family ethic. How overpopulation and climate change are affecting the morality of procreation. Cham, Switzerland: Springer. https://doi.org/10.1007/978-3-319-33871-2.

Ringard, A., Sagan, A., Sperre Saunes, I., \& Lindahl, A. K. (2013). Norway: health system review. Health Systems in Transition, 15(8), 1-162. https://apps.who.int/iris/handle/10665/330299 
Salvesen, I. (2016). Velger klima foran baby. Dagens Naringsliv. https://www.dn.no/magasinet/klima/ befolkning/biologi/rasmus-hansson/velger-klima-foran-baby/1-1-5564589

Sandberg, T. (2018). Slik når vi bærekraftmålene. Dagsavisen. https://www.dagsavisen.no/nyheter/innenriks/ slik-nar-vi-berekraftmalene-1.1218517

Sandvik, H. (2013). Vekst og humanisme. Morgenbladet. https://morgenbladet.no/debatt/2013/02/vekstog-humanisme

Skårderud, J. R. (2018). Etterlyst: Barn. Klassekampen. https://klassekampen.no/utgave/2018-12-05/ etterlyst-barn

Springmann, M., Clark, M., Mason-D'Croz, D., Wiebe, K., Bodirsky, B. L., Lassaletta, L., de Vries, W., Vermeulen, S. J., Herrero, M., Carlson, K. M., Jonell, M., Troell, M., DeClerck, F., Gordon, L. J., Zurayk, M., Scarborough, P., Rayner, M., Loken, B., Fanzo, J., \& Willett, W. (2018). Options for keeping the food system within environmental limits. Nature, 562, 519-525. https://doi.org/10. 1038/s41586-018-0594-0

Sundström, S. (2018). Sol i sikte? Klassekampen. https://klassekampen.no/utgave/2018-10-26/sol-i-sikte

Sveen, H. H. (Ed.). (2015). Evig barnefri. Historier om frivillig barnlфshet. Oslo: Humanist forlag.

Sæther, G. (2018). Kaster loss. Dagens Naringsliv. https://www.dn.no/magasinet/naringsliv/camillahagen-sorli/profil/future-talks/-vi-ma-snakke-om-fremtiden/2-1-396146

Sætre, S. (2013). Ekstrem-Randers. Morgenbladet. https://morgenbladet.no/samfunn/2013/ekstremranders

Tjøtta, S. (2013). Dr. Strangelove. Morgenbladet. https://morgenbladet.no/debatt/2013/dr_strangelove

Torvik, Y. G. (2019). Tilbake til røttene. Klassekampen. https://klassekampen.no/utgave/2019-08-21/ tilbake-til-rottene

Tvinnereim, E., Fløttum, K., Gjerstad, Ø., Johannesson, M. P., \& Nordø, Å. D. (2017). Citizens’ preferences for tackling climate change. Quantitative and qualitative analyses of their freely formulated solutions. Global Environmental Change, 46, 34-41. https://doi.org/10.1016/j.gloenvcha.2017.06.005

Ulvik, O. S. (1993). Selvvalgt foreldreskap. Nye betingelser-nye beslutningsprosesser. Tidsskrift for Norsk Psykologforening, 30, 1069-1080.

Valsiner, J. (2019). From causality to catalysis in the social sciences. In J. Valsiner (Ed.), Social Philosophy of Science for the Social Sciences. Theory and History in the Human and Social Sciences. Cham, Switzerland: Springer. https://doi.org/10.1007/978-3-030-33099-6_8.

Vollset, S. E., Goren, E., Yuan, C.-W., Cao, J., Smith, A. E., Hsiao, T., Bisignano, C., Azhar, G. S., Castro, E., Chalek, J., Dolgert, A. J., Frank, T., Fukutaki, K., Hay, S. I., Lozano, R., Mokdad, A. H., Nandakumar, V., Pierce, M., Pletcher, M., \& Murray, C. J. L. (2020). Fertility, mortality, migration, and population scenarios for 195 countries and territories from 2017 to 2100: A forecasting analysis for the global burden of disease study. The Lancet, 396(10258), 1285-1306. https://doi.org/10.1016/S0140-6736(20)30677-2

Washington, H., \& Cook, J. (2011). Climate change denial: Heads in the sand. London: Earthscan.

Watts, S. (2014). User skills for qualitative analysis: Perspective, interpretation and the delivery of impact. Qualitative Research in Psychology, 11(1), 1-14. https://doi.org/10.1080/14780887.2013.776156

Wiedswang, K. (2019). Det er bra hvis vi blir færre. Veien dit kan bli vond. Dagens Naringsliv. https:// www.dn.no/kommentar/det-er-bra-hvis-vi-blir-farre-veien-dit-kan-bli-vond/2-1-561024

Wiggins, S. (2017). DP and other forms of discourse analysis. In Discursive Psychology (pp. 31-58). SAGE Publications Ltd. https://doi.org/10.4135/9781473983335

Wynes, S., \& Nicholas, K. A. (2017). The climate mitigation gap: Education and government recommendations miss the most effective individual actions. Environmental Research Letters, 12, 074024. https:// doi.org/10.1088/1748-9326/aa7541

Publisher's Note Springer Nature remains neutral with regard to jurisdictional claims in published maps and institutional affiliations. 